nication, 1969). Many of our patients report an awakening reaction shortly after taking L-dopa, with symptoms resembling those following ingestion of amphetamine. These observations are compatible with the view that L-dopa causes release of amines from adrenergic nerve endings. The significant miosis we have observed with continuous oral $\mathrm{L}$ dopa therapy, like the hypotension, may reflect decreased peripheral sympathetic activity following noradrenaline depletion at sympathetic nerve endings. Since the drug causing depletion is itself a noradrenaline precursor such depletion might be only partial. This expectation is confirmed by the finding (Godwin-Austen et al., 1969a) that patients treated with L-dopa still show a mydriatic response to tyramine, which acts by releasing noradrenaline from nerve endings in the iris.

Diminished mydriasis with phenylephrine reported during L-dopa therapy has been attributed to $\alpha$-adrenergic receptor blockade by L-dopa or its metabolites (GodwinAusten et al., 1969a). A brisk mydriatic response to phenylephrine drops, however, still occurs in eyes treated with high concentrations of dopamine or L-dopa for several hours (Spiers and Calne, 1969; Calne and Spiers, 1970). Since prolonged application of high concentrations of a drug is a sensitive test for blocking activity, it seems unlikely that dopamine or L-dopa produces significant $\alpha$-blockade.

Miosis is not always detectable during L-dopa therapy; no change in resting pupillary size was detected in one series of 18 patients (Godwin-Austen et al., 1969a). Absence of miosis in these patients might be due to short duration of L-dopa therapy (Spiers, 1969) or to the timing of ocular photography. If this was done shortly after a dose of L-dopa the acute mydriatic effects of the drug, due to amine release, would mask the underlying chronic miosis, due to partial amine depletion. Timing of observations may well explain the occasional observation of hypertension instead of hypotension during L-dopa therapy, for intravenous administration of Ldopa to man produces an acute hypertensive response (Degkwitz, et al., 1960) which accords well with its acute mydriatic effects.

The effect of L-dopa and dopamine on adrenergic nerve endings may be more complex than simple noradrenaline depletion. Collins and West (1968) showed that incubation of rabbit ileum with dopamine or L-dopa leads to accumulation of dopamine within the sympathetic nerve terminals, and subsequent stimulation of the nerves releases dopamine. Burn (personal communication, 1969), suggested that in patients receiving L-dopa nerve impulses may release a normal amount of total catecholamines, but much of this will be dopamine, so the quantity of noradrenaline released by each impulse will be subnormal. Since dopamine has less capacity than noradrenaline to stimulate $\alpha$-adrenergic receptors (Goldberg et al., 1969), the effects of sympathetic nerve impulses will be diluted. Under these circumstances hypotension, miosis, and perhaps a reduced cardiac response to exercise are possible clinical results of L-dopa therapy.

An alternative explanation of all these observations is that L-dopa exerts its sympatholytic action centrally, possibly by modulating levels of brain amines.

We are indebted to the departments of medical photography, in particular Mr. R. Strutt, and medical illustration, University College Hospital Medical School. Professor D. R. Laurence gave helpful advice and discussion.

\section{REFERENCES}

Calne, D. B., Stern, G. M., Laurence, D. R., Sharkey, J., and Armitage, P. (1969a). Lancet, 1, 744.

Calne, D. B., Spiers, A. S. D., Stern, G. M., Laurence, D. R., and Armitage, P. (1969b) Lancet, 2, 973

Calne, D. B., Brennan, J., Spiers, A. S. D., and Stern, G. M. (1970). British Medical Fournal, 1, 474.

Calne, D. B., and Spiers, A. S. D. (1970). Contemporary Neurology. In press.

Carlsson, A., Lindqvist, M., Magnusson, T., and Waldeck, B. (1958). Science, 127, 471 .

Collins, G. G. S., and West, G. B. (1968). British fournal of Pharmacology, 34, 514 .

Cotzias, G. C., Papavasiliou, P. S., Gellene, R., and Aronson, R. B. (1968). Transactions of the Association of American Physicians, 81, 171.

Cotzias, G. C., Papavasiliou, P. S., and Gellene, R. (1969). New England fournal of Medicine, 280, 337.

Degkwitz, R., Frowein, R., Kulenkampff, C., and Mohs, U. (1960). Klinische Wochenschrift, 38, 120.

Eränkö, O., and Räisänen, L. (1968). Mechanisms of Release of Biogenic Amines, ed. U. S. Von Euler, S. Rossell, and B. Uvnäs, p. 73. London, Pergamon

Godwin-Austen, R. B., Lind, N. A., and Turner, P. (1969a). Lancet, 2, 1043 .

Godwin-Austen, R. B., Tomlinson, E. B., Frears, C. C., and Kok, H. W. L. (1969b). Lancet, 2, 165

Goldberg, L. I., Talley, R. C., and McNay, J. L. (1969). Progress in Cardiovascular Diseases, 12, 40.

Harrison, W. H., Levitt, M., and Udenfriend, S. (1963). Fournal of Pharmacology and Experimental Therapeutics, 142, 157.

Pennefather, J. N., and Rand, M. J. (1960). Fournal of Physiology, 154, 277.

Spiers, A. S. D. (1969). Lancet, 2, 1301.

Spiers, A. S. D., and Calne, D. B. (1969) British Medical fournal, 4 333 .

Yahr, M. D., Duvoisin, R. C., Hoehn, M. M., Schear, M. J., and Barrett, R. E. (1968). Transactions of the American Neurological Association, 93, 56.

Yahr, M. D., Duvoisin, R. C., Schear, M. J., Barrett, R. E., and Hoehn, M. M. (1969). Archives of Neurology, 21, 343.

\title{
Eroded Cervix
}

\author{
UNA M. KROLL, ${ }^{*}$ M.B., B.CHIR., M.R.C.G.P.
}

$S^{n}$ ummary: During a six-year period 1,808 women aged 20 to 59 underwent gynaecological examination at a well-woman clinic. Cervical erosions were found in 269. Nine patients had cervical carcinoma, confirmed by biopsy; of these eight had eroded cervices. The remaining patients with non-malignant erosions were examined at six-monthly intervals. Of these, roughly $39 \%$ showed spontaneous healing within a year, $31 \%$ responded to medical treatment, $17 \%$ healed only after surgical treatment, $9 \%$ remained unhealed when reviewed six months after the last active treatment, and $4 \%$ relapsed after originally healing well.

The difficulties of getting patients to return for cytological examination increase with the interval between the original examination and recall. It is suggested that

* General Practitioner, St. Paul's Cray, Kent. patients should be re-examined initially at an interval not exceeding six months, so that false negative results are minimal.

\section{Introduction}

The value of cervical cytology in the diagnosis of carcinoma of the uterine cervix is now well established. Its practical application has been shown among patients attending hospital (Yule and Cameron, 1961), local authority clinics (Jones and Metcalfe Brown, 1965), and general practice clinics (MacGregor and Baird, 1963). The relation of carcinoma to other abnormalities of the uterine cervix is also well documented. Stoll (1958), in a review of 16,749 patients, found the incidence of carcinoma in clinically eroded cervices to be 26 times more common than in clinically normal cervices. In his survey the incidence of all types of carcinoma was $1: 1,345$ in macrosco- 
pically smooth cervices, while in those clinically eroded it was $1: 53$.

Non-malignant erosions were also studied. They can be classified aetiologically. There are the congenital erosions of Virchow, found in children and virgins, in which there is no histological evidence of infection. The aetiology of these is unknown but may be a hormonal imbalance, possibly an overproduction of oestrogens. In pregnancy some erosions may also have this origin, though histological examination of these may show evidence of trauma and infection. True acquired or inflammatory erosions arise because of a response by the epithelium to inflammation or to trauma. Trauma is the commonest feature of the postnatal erosions, whereas infection is the commonest aetiological factor in the acquired erosions so commonly associated with chronic cervicitis. In chronic cervicitis the erosion is the outward manifestation of the inflammatory process set up by bacterial infection. Bacterial action destroys the squamous epithelium of the cervix. This may be replaced by columnar epithelium. When healing takes place the squamous cells again push the columnar cells back to the region of the os.

Strictly speaking, the diagnosis of cervical erosion can be made only after histological examination of a biopsy specimen. On the surface the stratified epithelium is replaced in part or wholly by columnar epithelium that dips down from the surface to form crypts and glands which often show cystic distension. Hyperaemia and round-cell infiltration of the interstitial tissue are present. These changes can complicate chronic cervicitis or acute cervicitis, especially where the latter is due to a flare-up of a chronic infection rather than to the gonococcus. The clinical entity of what constitutes a cervical erosion is harder to define.

Clinically an erosion is said to be present when an area of brightish red granular appearance is seen at the cervical os, often covered by mucus. The intense vascularity of the base of the erosion contributes to its red appearance. The area of an erosion may be irregular in outline and may affect only one lip of the cervix, but it often appears as a fairly regular circle around the os, The clinical diagnosis is greatly assisted by use of the Schiller staining technique and by culdoscopy. These aids to diagnosis are not generally available in general practice, where the diagnosis has to be made on appearance alone in most cases.

There is no specific cytological picture diagnostic of an erosion. According to Wachtel (1964), its presence may be suspected if large numbers of endocervical cells are recovered from the scrapings taken from the erosion surface while avoiding contact with the squamo-columnar junction. The overall pattern is one of inflammation. The greatest value of cytology in the assessment of cervical erosions is in the differential diagnosis between simple and malignant erosions.

\section{Method}

The object of this study was to determine the occurrence rate, clinical course, and inter-relationship of cervical erosions with other diseases affecting the cervix in a group of women who were self-selected by their desire to attend an open gynaecological clinic run by a family doctor. The practice was situated on a large urban housing estate, most of the population being of social classes III and IV. There were 3,385 women aged 20 to 59 in a group practice of 12,000 . The study covered the years 1963-8 inclusive. The method throughout was uniform. Well patients were encouraged by literature or personal invitation to attend for gynaecological screening. Twice-weekly clinics were held, at which premarital examinations, postnatal examinations, and examinations in connexion with contraceptive advice were also carried out. At every consultation cervical smears were taken routinely by direct vision and with an Ayre-type spatula. Aspirations from the posterior fornix were taken only when the history suggested endocervical pathology or where the direct visual method was impossible. Bimanual examination was always carried out.

Slides were stained by the Papanicolaou method and examined by me. They were cross-indexed and numbered only, so that clinical bias was eliminated so far as was possible. All cases with abnormal cytology suspicious of malignancy were referred to King's College Hospital. Other patients requiring surgical advice were treated at local hospitals.

Treatment of every patient was based on clinical grounds taken in conjunction with the appearance of the cervical smear, which was examined before a decision was made on the management of the patient. Treatment was not instituted simply because of an abnormal clinical appearance of the cervix. Unless the cytology showed suspicion of malignancy, treatment was instituted only in the presence of symptoms distressing to the patient. In the first instance treatment was always medical, by pessaries of the prescribing doctor's choice. If medical treatment failed, then surgical cautery was advised. In all cases of cervical erosion patients were recalled for examination after six months and then at six-monthly intervals. When treatment was necessary, patients were examined six weeks after treatment was completed and then at six-monthly intervals. More frequent examinations were made if the cytology was abnormal but not sufficiently so to warrant biopsy.

\section{Results}

A total of 3,385 women fell within the age limits of 20 and 59 , of whom 1,808 attended on one or more occasions; the percentage for each age group is shown in Table I.

TABLE I

\begin{tabular}{|c|c|c|}
\hline Age Group & $\begin{array}{l}\text { No. of Patients } \\
\text { Available }\end{array}$ & $\begin{array}{l}\text { No. of Patients } \\
\text { Attending }\end{array}$ \\
\hline $\begin{array}{l}20-29 \text { years } \\
30-39 " \# \\
40-49 " \# \\
50-59 " \#\end{array}$ & $\begin{array}{r}845 \\
653 \\
1,112 \\
775\end{array}$ & $\begin{array}{l}317(37.5 \%) \\
390(59 \%) \\
745(66.9 \%) \\
356(45.8 \%)\end{array}$ \\
\hline Total & 3,385 & $1,808(53 \cdot 4 \%)$ \\
\hline
\end{tabular}

The incidence of cervical erosions within this population is shown according to age group in Table II. The 269 cases of erosion were further analysed in detail as shown in Table III.

TABLE II

\begin{tabular}{c|c|c}
\hline Age Group & $\begin{array}{c}\text { Total } \\
\text { Examinations }\end{array}$ & Cervical Erosions \\
\hline $20-29$ & 317 & $56(17 \cdot 6 \%)$ \\
$30-39$ & 390 & $79(20 \cdot 2 \%)$ \\
$40-49$ & 745 & $109(14 \cdot 7 \%)$ \\
$50-59$ & 356 & $25(7.0 \%)$ \\
\hline Total & 1,808 & $269(14 \cdot 8 \%)$ \\
\hline
\end{tabular}

TABLE III

\begin{tabular}{c|c|c|c|c}
\hline $\begin{array}{c}\text { Age } \\
\text { Group }\end{array}$ & $\begin{array}{c}\text { Simple } \\
\text { Erosions }\end{array}$ & $\begin{array}{c}\text { Erosions } \\
\text { Cervicitis }\end{array}$ & $\begin{array}{c}\text { Postnatal } \\
\text { Erosions }\end{array}$ & Total \\
\hline $20-29$ & 40 & 4 & 12 & 56 \\
$30-39$ & 52 & 21 & 6 & 79 \\
$40-49$ & 86 & 23 & & 109 \\
$50-59$ & 21 & 52 & 18 & 269 \\
\hline Total & 199 & 52 & \\
\hline
\end{tabular}


In the hreakdown of these figures simple erosions are those in which the characteristic appearances of inflammation and redness are present clinically, together with the cytological picture of inflammation. Erosions + cervicitis are those in which purulent exudate was noted and in which the infective organism could be isolated.

Of the 269 patients diagnosed as having cervical erosions on clinical grounds 47 left the area or died during the period of the survey, and a further 49 refused to attend again, so that $173(77.9 \%$ of the total numbers available) patients were followed up as described in the previous section. Only eight simple postnatal erosions were found among these patientsfive healed spontaneously after six months, two healed with medical treatment, and one patient had a persistent erosion after medical treatment but refused surgical treatment.

A total of 130 patients had simple erosions. Their progress at the end of a year from the date of diagnosis is shown in Table IV. Thirty-five had erosions with infective cervicitis; these were all chronic cases. No acute cases presented at the well-woman clinic. The progress of these women is shown in Table V.

TABLE IV

\begin{tabular}{c|c|c|c|c|c}
\hline $\begin{array}{c}\text { Age } \\
\text { Group }\end{array}$ & $\begin{array}{c}\text { Healed } \\
\text { Spontane- } \\
\text { ously }\end{array}$ & $\begin{array}{c}\text { Healed } \\
\text { Medically }\end{array}$ & $\begin{array}{c}\text { Healed } \\
\text { Surgically }\end{array}$ & Unhealed & Relapsed \\
\hline $20-29$ & 9 & 7 & 2 & 2 & 0 \\
$30-39$ & 14 & 16 & 4 & 5 & 1 \\
$40-49$ & 28 & 11 & 10 & 4 & 3 \\
$50-59$ & 8 & 2 & 3 & 11 & 5 \\
\hline Total & 59 & 36 & 19 & 11 & \\
\hline
\end{tabular}

\begin{tabular}{c|c|c|c|c|c}
\multicolumn{9}{c}{ TABLE V } \\
$\begin{array}{c}\text { Age } \\
\text { Group }\end{array}$ & $\begin{array}{c}\text { Healed } \\
\text { Spontane- } \\
\text { ously }\end{array}$ & $\begin{array}{c}\text { Healed } \\
\text { Medically }\end{array}$ & $\begin{array}{c}\text { Healed } \\
\text { Surgically }\end{array}$ & Unhealed & Relapsed \\
\hline $20-29$ & 0 & 2 & 2 & 0 & 0 \\
$30-39$ & 3 & 6 & 3 & 2 & 0 \\
$40-49$ & 1 & 7 & 4 & 1 & 2 \\
$50-59$ & 0 & 1 & 1 & 0 & 0 \\
\hline Total & 4 & 16 & 10 & 3 & 2 \\
\hline
\end{tabular}

In addition to these non-malignant cases of eroded cervices there were nine confirmed cases of carcinoma, eight of which had the clinical appearance of simple cervical erosion, though in one case the friability of the cervix made the case clinically suspect. The remaining patient had carcinoma-insitu in an apparently normal cervix. The invasive carcinomas were all found in eroded cervices, one in each of the age groups except the youngest. There were two cases of carcinoma-in-situ in the 30-39 age group and four in the 40-49 age group, three of which occurred in eroded cervices.

Of the 1,808 patients examined, $1,162(64.2 \%)$ had normal cervices, $269(14.8 \%)$ had erosions with or without concurrent cervicitis, $305(16.8 \%)$ had chronic cervicitis, and $64(3.5 \%)$ had polyps. Among these there were nine cases of carcinoma of the cervix. Eight others had lacerations.

\section{Cytology}

In all cases of erosion found to be malignant with invasive carcinoma the diagnosis could have been made on the first smear. One slide which showed a few malignant cells in 1963 was mistakenly passed as normal. A second slide in 1966 at the usual three-year period, accepted as the norm in this area, showed numerous malignant cells. This patient, whose cervix was clinically normal in 1963, had stage I invasive cervical carcinoma by 1966, and died just over a year later despite intensive radical treatment. Neither of the other two patients with early invasive carcinoma had any symptoms. One, aged 52, was treated by radium implantation followed by Wertheim's hysterectomy. The other, aged 32, had an extended hysterectomy with a vaginal cuff. Both were well five and three years after their respective operations.

The remaining patients with carcinoma-in-situ had total hysterectomies, since none fell in the 20-29 age group and none wished for more children. Two of these patients showed progression from basal dyskaryosis to frankly malignant-type smears. In one of these, aged 36 , with a clinically eroded cervix, this progression took place over a period of 18 months. In the other patient, aged 40 and with a normal cervix, progression occurred more slowly over a period of three years.

The incidence of atypia which was not malignant was totally unrelated to the appearance of the cervix. In 55 cases during the six-year period the atypia was shown to be due to infection with Trichomonas vaginalis and disappeared after appropriate treatment. No case of postnatal erosion showed atypia. In Table VI atypia refers to grade III type smears (international classification) only.

TABLE VI.-Atypia in Erosions Without Definite Suspicion of Malignancy

\begin{tabular}{|c|c|c|c|c|c|}
\hline $\begin{array}{l}\text { Age } \\
\text { Group }\end{array}$ & No. & Atypia & $\begin{array}{l}\text { Spontaneous } \\
\text { Disappearance }\end{array}$ & $\begin{array}{l}\text { Disappearance } \\
\text { after Medical } \\
\text { Treatment }\end{array}$ & Biopsy \\
\hline $20-29$ & 24 & 3 & 1 & 1 & \multirow{4}{*}{$\begin{array}{l}1 \text { (squamous } \\
\text { metaplasia) } \\
3(2 \text { squamous } \\
\text { metaplasia) } \\
10(1 \text { squamous } \\
\text { metaplasia) } \\
4\end{array}$} \\
\hline $30-39$ & 54 & 6 & 0 & 3 & \\
\hline $40-49$ & 71 & 16 & 2 & 4 & \\
\hline $50-59$ & 16 & 5 & 1 & 0 & \\
\hline Total & 165 & 30 & 4 & 8 & 18 \\
\hline
\end{tabular}

\section{Discussion}

Admittedly this series is small, and elaborate methods of diagnosis such as culdoscopy were not available. Though the overall rate of follow-up of all patients was only about $54 \%$, the follow-up rate of those with erosions, who received special attention by way of encouragement and recall letters, was $78 \%$-which seems the most that can be hoped for in a general practice over a period of several years-rather than judging by the initial enthusiastic response which inevitably follows the introduction of any new scheme. There is, as yet, no large-scale statistical proof of the overall response of patients to recall for screening, nor is the optimum frequency of repeat screening yet decided at national level. It is my clinical impression that the response of patients to recall after six months was much higher than response after an interval of three years, but insufficient time has elapsed to provide evidence of this.

The high rate of spontaneous healing of acquired erosions in this series is evidence to support the clinical policy of laissez-faire where the treatment of uncomplicated erosions is concerned. Provided the cytology is normal, nature can be left to effect its cure unless symptoms warrant treatment. In this series about $39 \%$ of all erosions had healed one year after the initial diagnosis, $31 \%$ healed with medical treatment alone, $17 \%$ failed to respond and were treated by biopsy and diathermy cautery under general anaesthesia, 9\% remained unhealed or had relapsed within a year of treatment, and $4 \%$ relapsed after a longer interval.

Atypia in erosions, grades IIIa and IIIb, warrant the closest observation. In this series progression was observed only to grade IV where the original grading had been grade IIIa. In view of the known incidence of missed "positive" smears it is 
suggested that a repeat smear should be taken in all cases within six months of the original smear. Thereafter the national three-year or five-year programme seems adequate.

The study was carried out with the aid of equipment and an expenses grant from the Medical Research Council. I am indebted to Sir John Peel P.R.C.O.G., for training in the clinical aspects of the subject and for his encouragement, and to the late Professor $\mathrm{H}$. A. Magnus, of King's College Hospital, under whom I was trained in cytology. I would like to thank my partners, Drs. I. N. Manser, J. D. Paulett, E. Tuckman, and J. T. Woodall, for access to patients under their care. I am grateful to my secretary-reception- ist, Mrs. Janis Wilson, whose help contributed a great deal to the smooth running of the survey.

\section{REFERENCES}

Jones, A. E., and Brown, C. M. (1965). Lancet, 1, 543.

MacGregor, J. E., and Baird, D. (1963). British Medical fournal, 1, 1631 Stoll, P. (1958). Acta; Unio Internationalis Contra Cancrum, p. 314. Wachtel, E. G. (1964). Exfoliative Cytology in Gynaecological Practice. London, Butterworths.

Yule, R, and Cameron, F. D. H. (1961). Fournal of Obstetrics and Gynaecology of the British Commonwealth, 68, 658.

\section{Preliminary Communications}

\section{Study of the Clinical Efficiency of Bleomycin in Human Cancer}

\author{
British Medical fournal, 1970, 2, 643-645
}

\begin{abstract}
Summary: A trial of the action of bleomycin was made on 237 cancer patients with tumours in a visible and actively growing phase who did not require surgery or radiotherapy. Bleomycin was found to have several special properties-absence of haemopoietic toxicity or immunosuppressive action and toxic side-effects affecting skin, mucosae, and lungs. The drug is more effective than drugs previously available for squamous cell carcinoma of the skin and cancer of the penis, the vulva, oesophagus, and uterine cervix, as well as for melanoma and mycosis fungoides. It is at least as effective as those drugs or combinations of drugs previously used for oropharyngeal tumours and testicular dysembryoma or choriocarcinoma. It is very effective when used in arterial perfusion therapy of otorhinolaryngeal tumours. It is of little value in other tumours, in particular for those of the haemopoietic system.
\end{abstract}

\section{INTRODUCTION}

Bleomycin was discovered by Umezawa (1965) in the fermentation products of a line of Streptomyces verticillus; it is a basic peptide with a molecular weight about 1,400 . Systematic testing showed that bleomycin has a cytostatic effect on tumour cells. Bleomycin has proved to be effective against some spontaneous tumours in dogs (Ishizuka et al., 1967). The mechanism of the cytostatic action of bleomycin is not completely understood. It is known to inhibit the incorporation of thymidine into D.N.A. and the activity of D.N.A. polymerase in cells sensitive to this antibiotic. An experimental study of its toxicity and distribution (Ishizuka et al., 1967) emphasized high affinity for skin, lung, and squamous cell carcinomas and the insensitivity of haemopoietic tissues. Hayat and Mathé (1970) showed that bleomycin has an immunosuppressive effect as indicated by the Jerne plaque test.

\section{Patients and Methods}

The trial lasted from 1 July to 15 December 1969, and was made on 237 patients with tumours in the visible and growing phase. The choice of patients to be treated was not random; they received only a single course of treatment and all were in a condition in which chemotherapy was reasonably indicated. We used the new drug in primary tumours of the skin or penis only when surgical excision or radiotherapy was not possible. Distribution of the patients according to their type of neoplasm is shown in Table I, which also shows how the drug was given.

TABLE I.-Location and Histological Type of Tumours Treated with Bleomycin

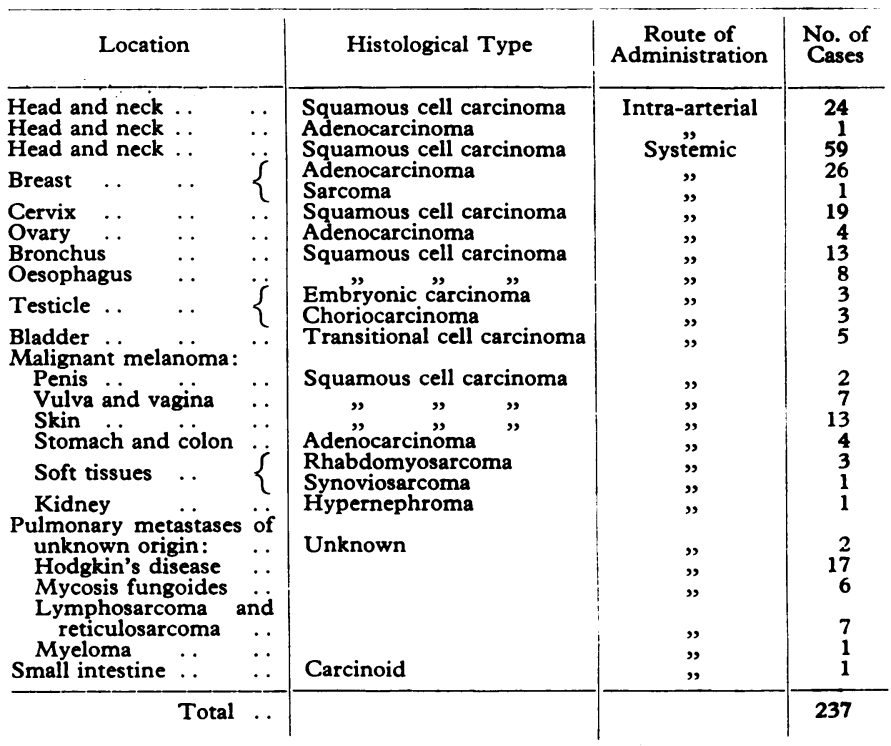

Regional arterial perfusion was used in 25 patients with tumours of the head and neck (only 24 cases could be evaluated)-six had cancer of the tonsil, six cancer of the tongue, two pharyngeal cancer, six cancer of the floor of the mouth, two tumours of the cheek, one tumour of the pterygomaxillary fossa, and two tumours of the maxillary antrum.

The daily dose was $10-20 \mathrm{mg} . / \mathrm{sq} . \mathrm{m}$.; the course lasted 6 to 14 days, with a mean of 10 days. The drug was given by arterial perfusion lasting from 12 to 24 hours each day.

The remaining patients were given bleomycin systemically, either intravenously or intramuscularly. Most of them received $10-20 \mathrm{mg} . / \mathrm{sq} . \mathrm{m}$./day for 10 to 38 days, equal to a total dose of $150-820 \mathrm{mg}$.; in some patients $20 \mathrm{mg}$./sq.m. was given intravenously twice a week.

The toxic effects of the drug on all tissues, organs, and functioning systems, including the immune reactions, were assessed. The results of treatment were assessed by comparing the growth of the tumour during treatment with bleomycin with the tumour growth rate before treatment, when no chemotherapy had been given (control period). 